\title{
Correlation of Helicobacter pylori Genotypes with Gastric Histopathology in the Central Region of a South-European Country
}

\author{
Nuno Almeida $\cdot$ Maria Manuel Donato $\cdot$ José Manuel Romãozinho • \\ Cristina Luxo - Olga Cardoso - Maria Augusta Cipriano - Carol Marinho • \\ Alexandra Fernandes $\cdot$ Carlos Sofia
}

Received: 17 March 2014/ Accepted: 1 August 2014/Published online: 21 August 2014

(C) Springer Science+Business Media New York 2014

\begin{abstract}
Background Outcome of Helicobacter pylori (H. pylori) infection results from interaction of multiple variables including host, environmental and bacterial-associated virulence factors.

Aim This study aimed to investigate the correlation of $c a g A, c a g E, v a c A, i c e A$ and $b a b A 2$ genotypes with gastric histopathology and disease phenotype in the central region of a South-European country.

Methods This prospective study involved 148 infected patients (110 female; mean age $43.5 \pm 13.4$ years) submitted to endoscopy with corpus and antrum biopsies. $H$. pylori was cultured and DNA extracted from the isolates. Genotypes were determined by PCR. Histopathological features were graded according to the updated Sydney system and OLGA/OLGIM classification. Only patients with single $H$. pylori genotypes and complete histopathological results were included.
\end{abstract}

\footnotetext{
N. Almeida $(\bowtie) \cdot$ J. M. Romãozinho · A. Fernandes · C. Sofia

N. Almeida $(\varangle) \cdot$ J. M. Romãozinho · A. Fernandes · C. Sofia
Gastroenterology Department, Coimbra University Hospital Centre, Praceta Mota Pinto e Avenida Bissaya Barreto, 3000-075 Coimbra, Portugal

e-mail: nunoperesalmeida@gmail.com

J. M. Romãozinho

e-mail: jmromaozinho@gmail.com

\author{
A. Fernandes \\ e-mail: xanafmuc@hotmail.com \\ C. Sofia \\ e-mail: carlos.sofia@huc.min-saude.pt
}

M. M. Donato · J. M. Romãozinho · C. Sofia

Gastroenterology Centre, Faculty of Medicine, Coimbra

University Hospital Centre, Praceta Mota Pinto e Avenida

Bissaya Barreto, 3000-075 Coimbra, Portugal

e-mail: mariamanueldonato@gmail.com

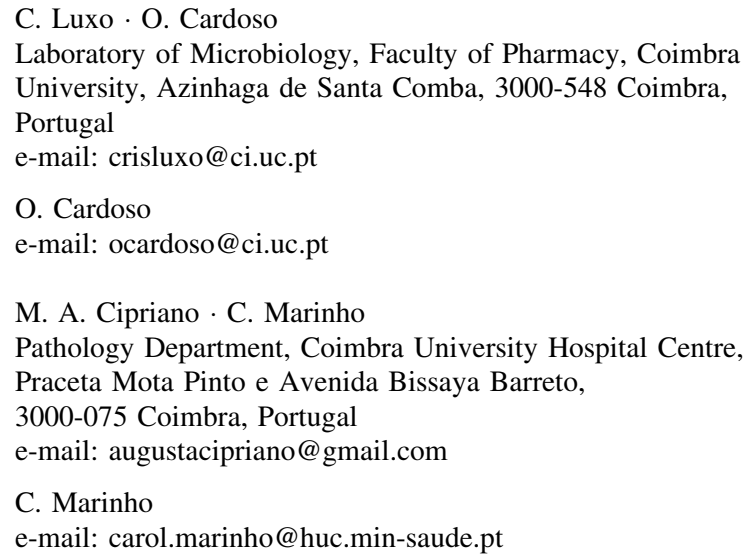

Results Antrum samples presented higher degrees of atrophy, intestinal metaplasia, chronic inflammation and neutrophil activity. Genotype distribution was as follows: cagA-31.8 \%; cagE-45.9\%; vacA s1a-24.3\%; vacA s1b$19.6 \%$; vacA s1c-0.7\%; vacA s2-55.4\%; vacA m1$20.9 \%$; vacA m2-79.1 \%; vacA s1m1-18.9 \%; vacA s1m2$25.7 \%$; vacA s2m1-2\%; vacA s2m2-53.4\%; iceAl$33.8 \%$; iceA2-66.2 \%; babA2-12.2 \%. CagA genotype was metrity, chronic inflammation and OLGIM stages. BabA2 was linked with higher H. pylori

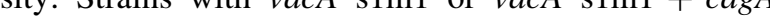
ulcer and $v a c A \mathrm{~s} 2 \mathrm{~m} 2$ with iron-deficient anemia.

Conclusions cagA, vacA s1m1 and babA2 genotypes are relatively rare in the central region of Portugal. cagApositive strains are correlated with more severe histopathological modifications. This gene is commonly associated 
with vacA $\mathrm{s} 1 \mathrm{~m} 1$, and such isolates are frequently found in patients with peptic ulcer.

Keywords Helicobacter pylori - Genotype - Gastritis · Histopathology $\cdot \operatorname{cag} A \cdot \operatorname{vac} A$

\section{Introduction}

Helicobacter pylori (H. pylori) infection affects an estimated $50 \%$ of the global population [1]. It is associated with multiple gastric pathologies, including gastritis, gastroduodenal ulcer disease, gastric adenocarcinoma and mucosa-associated lymphoid tissue (MALT) lymphoma [2]. Approximately, $84.2 \%$ of Portuguese adults are infected by $H$. pylori [3]. However, there is not a direct correlation between the prevalence of infection and the prevalence of $H$. pylori related manifestations since only approximately 10-20\% of those infected develop clinical disease. This occurs because the severity of disease manifestations is influenced by multiple variables, including host genetic diversity, environmental factors and $H$. pylori genetic heterogeneity [4].

Several genes, such as $\operatorname{cag} A, \operatorname{cag} E, v a c A$, ice $A$, and $b a b A 2$, have been identified as markers for enhanced pathogenicity of $H$. pylori. The cagA gene (cytotoxinassociated gene) is a marker of the pathogenicity island gene (cagPAI) presence. Infection with cagA-positive strains is associated with a greater inflammatory response and an increased risk of adverse clinical outcomes including atrophic gastritis and gastric cancer [5, 6]. cagE is another marker gene for cagPAI and has also been associated with a more severe clinical outcome by stimulating the production of several cytokines from infected epithelial cells [7].

The vacuolating cytotoxin gene (vacA) is present in all H. pylori strains and comprises variable regions (signal-s, middle-m and intermediate-i). VacA protein is a potent cytotoxin that induces host cell vacuolation and, ultimately, cell death [8]. There are different allele variations for this gene, including for the signal (s1a, s1b, s1c, s2) and middle region ( $\mathrm{m} 1$ and $\mathrm{m} 2$ ). The mosaic combination of these allelic types determines the level of cytotoxin produced and, eventually, the histopathological modifications and gastrointestinal manifestations. Strains with vacA s1 and $\mathrm{m} 1$ alleles produce a large amount of toxin and epithelial damage, whereas s 2 and $\mathrm{m} 2$ genotypes produce little or no toxin [8, 9]. Most vacA s1 strains are cagA-positive, thus the two markers are closely related [9, 10].

The gene iceA (induced by contact with epithelium) has two main allelic variants, iceAl and iceA2. Expression of iceAl is upregulated on contact of $H$. pylori with human epithelial cells and may be linked with peptic ulcer disease [11].
The blood group antigen binding adhesin (BabA), a protein encoded by the $b a b A 2$ gene, binds to Lewis $\mathrm{b}$ antigens and ABO antigen [12]. There are three alleles for $b a b A$ gene but only the $b a b A 2$ gene product is functionally active. The presence of this gene has been associated with gastric cancer [13].

The distribution of $H$. pylori genotypes and its correlation with histological modifications and disease outcomes presents geographic differences. The present study aimed to investigate whether there is any association of $\operatorname{cag} A$, $c a g E$, vacA, ice $A$ and babA2 genotypes with clinical presentation and gastric histological modifications in $H$. pylori infected patients from the central region of Portugal.

\section{Patients and Methods}

\section{Patients}

In this single-center study, consecutive patients with nonulcer dyspepsia, peptic ulcer, iron-deficient anemia, indication for chronic therapy with proton pump inhibitors (PPI) and/or first-degree relatives with gastric carcinoma were prospectively considered for inclusion. All of them had a positive ${ }^{13} \mathrm{C}$-urea breath test and indication for upper endoscopy. Exclusion criteria were: age $<18$ years; pregnancy; lactating and/or fertile women who were not using safe contraceptive methods; history of allergy/hypersensitivity to any antibiotic or PPI; previous gastric malignancy and/or gastric surgery; current use of anticoagulants; marked thrombocytopenia; systemic severe disease (hepatic, cardio-respiratory or renal disease; uncontrolled diabetes; active malignant diseases, coagulopathies); use of antibiotics in the last 4 weeks; use of PPI in the last 2 weeks.

\section{Study Design}

All patients were submitted to upper endoscopy with four biopsies in the antrum and four in the corpus, always including a biopsy from incisura angularis. The first two biopsies from the antrum and from the corpus were immediately placed in independent containers of adequate transport media-Portagerm pylori (bioMérieux Portugal, Linda-A-Velha, Portugal)_at $4{ }^{\circ} \mathrm{C}$, and sent to microbiology laboratory. Urease test and Gram staining of a smear prepared from the biopsy specimen were performed to confirm the presence of $H$. pylori. After manual grinding with disposable material, the samples were distributed directly in agar pylori (bioMérieux Portugal, Linda-AVelha, Portugal). Cultures were incubated for a minimum of $72 \mathrm{~h}$ and a maximum of 10 days at $37^{\circ} \mathrm{C}$ under microaerophilic conditions, produced with $\mathrm{H}_{2}-\mathrm{CO}_{2}-$ 
generating packs (GENbox Microaer, bioMérieux Portugal, Linda-A-Velha, Portugal). H. pylori isolates were identified by colony morphology, characteristic spiral morphology on Gram staining, and positive catalase, urease and oxidase tests.

The other biopsy specimens, for histological studies, were fixed in $10 \%$ formaldehyde. Formalin-fixed, paraffinembedded tissue, after cutting and adequate deparaffination, was then submitted to traditional staining with hematoxylin + eosin, modified Giemsa and WarthinStarry. Histological findings were described according to the modified Sydney criteria [14]. Two different pathologists, blinded to the genotype results, independently reviewed all slides and evaluated the following histopathological parameters: H. pylori density, chronic inflammation (mononuclear infiltration), polymorphonuclear activity (neutrophil activity), intestinal metaplasia and glandular atrophy. These items were scored on an ordinal scale: 0—absent; 1-mild; 2-moderate; 3-severe. Both pathologists discussed discrepant results and a final grading was established by consensus. For practical reasons, we divided glandular atrophy and intestinal metaplasia in two groups ( 0 -absent; 1 to 3 -present) and neutrophil activity, chronic inflammation and $H$. pylori colonization density also in two groups $(0+1$-absent or mild; $2+3-$ moderate or severe). Gastritis stage was also assessed according to the international Operative Link on Gastritis Assessment (OLGA) and Operative Link on Intestinal Metaplasia Assessment (OLGIM) [15-17].

Antrum and corpus samples were processed separately, and we excluded patients with incomplete histological results.

\section{H. pylori Genotyping}

DNA extraction from pure culture of $H$. pylori was performed with a special extraction kit (QIAamp ${ }^{\circledR}$ DNA Mini Kits, QIAGEN, Izasa Portugal, Carnaxide, Portugal) according to manufacturer's instructions.

The cagA, cagE, vacA (s1a, s1b, s1c, m1, m2), iceA (A1, A2), and babA2 genotypes were determined with real-time PCR molecular technique by using specific primers selected from previously published works (Table 1) [9, 18-22]. For $\operatorname{cag} A$, we used two sets of primers. A $\operatorname{cag} A$-positive status was defined when $\operatorname{cag} A$ gene was detected by at least one of the two primer pairs.

PCR was performed in a volume of $20 \mu$ containing $4.0 \mu$ of LightCycler FastStart DNA MasterPLUS SYBR ${ }^{\circledR}$ Green I (Roche Diagnostics, Mannheim, Germany), $0.5 \mu \mathrm{M}$ of each specific primers, $13.0 \mu \mathrm{l}$ of $\mathrm{H}_{2} 0$ PCR grade and $2.0 \mu \mathrm{l}$ of DNA extract. An initial denaturation cycle at $95{ }^{\circ} \mathrm{C}$ for $10 \mathrm{~min}$ was performed in all cases followed by 45 amplification cycles. Specific denaturation, annealing and extension conditions for each set of primers are expressed in Table 1. PCR products were checked on $2 \%$ agarose gels stained with ethidium bromide and transilluminated with UV light. Base-pair ladder size markers were added (E-Gel ${ }^{\circledR}$ Quantitative DNA Ladder, Invitrogen, Carlsbad, USA), and positive and negative controls were always included. Melting curves were also plotted automatically and analyzed with the LightCycler software. By comparing both results, it was possible to establish specific melting temperatures to identify each gene. To avoid any methodological error a different technician, blinded to previous results, repeated all procedures. Positive and negative controls were included.

Antrum and corpus specimens were processed separately. If multiple strains were identified or if it was not possible to determine $\operatorname{cagA}$, $\operatorname{cag} E$, vacA, iceA and/or $b a b A 2$ status the patient was excluded.

\section{Statistical Analysis}

The chi-square test and Fisher's exact test were used to assess the relationship between individual genotypes and the presence of neutrophil activity, chronic inflammation, colonization density, atrophy and intestinal metaplasia. The same tests were performed to evaluate the relationship between individual genotypes and clinical manifestations and/or reason for $H$. pylori eradication. For multiple comparisons involving the five genes, a Bonferroni correction was applied and only $p$ values less than 0.01 were considered statistically significant.

For each gene, a comparison of histopathological scores was also performed with Mann-Whitney test. Paired sample Wilcoxon test was used to compare antrum and corpus scores.

The correlation of the ten histopathological phenotypes with clinical variables was also performed with the abovementioned tests, and the Bonferroni-adjusted $p$ value was 0.005 .

Logistic regression model was obtained for each histopathological phenotype using genotypes cagA, cagE, vacA, ice $A$ and babA2 as factors. Age, alcohol consumption, tobacco consumption, local of residence and gender were included as possible confounders. Results of logistic regression were expressed as odds ratios (OR) with $95 \%$ confidence intervals (CI), and a p value less than 0.05 was accepted as statistically significant.

Data were analyzed in SPSS version 20.0 (IBM, Illinois, US).

\section{Ethical Considerations}

The study was approved by the ethical committee of our Hospital and the Faculty of Medicine and performed in 
Table 1 Specific primers for detection of cagA, cagE, vacA, iceA and babA2 genes

\begin{tabular}{|c|c|c|c|c|c|}
\hline Gene & Primer & Primer sequence $\left(5^{\prime}-3^{\prime}\right)$ & PCR conditions & $\begin{array}{l}\text { PCR product } \\
\text { (bp) }\end{array}$ & Reference \\
\hline \multirow[t]{4}{*}{$\operatorname{cag} A$} & A1 & CCATGAATTTTTGATCCGTTCGG & \multirow[t]{2}{*}{$95^{\circ} \mathrm{C}, 10 \mathrm{~s} ; 62^{\circ} \mathrm{C}, 5 \mathrm{~s} ; 72^{\circ} \mathrm{C}, 16 \mathrm{~s}$} & \multirow[t]{2}{*}{394} & \multirow[t]{2}{*}[18]{} \\
\hline & $\mathrm{A} 2$ & GATAACAGGCAAGCTTTTGAGGGA & & & \\
\hline & A3 & ATGGGGAGTCATGATGGCATAGAACC & \multirow[t]{2}{*}{$95{ }^{\circ} \mathrm{C}, 10 \mathrm{~s} ; 62{ }^{\circ} \mathrm{C}, 5 \mathrm{~s} ; 72{ }^{\circ} \mathrm{C}, 16 \mathrm{~s}$} & \multirow[t]{2}{*}{717} & \multirow[t]{2}{*}[18]{} \\
\hline & A4 & ATTAGGCAAATTAAAGACAGCCACC & & & \\
\hline \multirow[t]{2}{*}{$\operatorname{cag} E$} & Forward & AGACATGCAAAAAGGTAT & \multirow[t]{2}{*}{$95^{\circ} \mathrm{C}, 10 \mathrm{~s} ; 46^{\circ} \mathrm{C}, 5 \mathrm{~s} ; 72^{\circ} \mathrm{C}, 37 \mathrm{~s}$} & \multirow[t]{2}{*}{900} & \multirow[t]{2}{*}{ [19] } \\
\hline & Reverse & CAATCTAGTGGGGTGGTA & & & \\
\hline \multirow[t]{3}{*}{$v a c A \mathrm{~s} 1 / \mathrm{s} 2$} & Forward & ATGGAAATACAACAAACACAC & \multirow[t]{3}{*}{$95{ }^{\circ} \mathrm{C}, 10 \mathrm{~s} ; 53^{\circ} \mathrm{C}, 5 \mathrm{~s} ; 72^{\circ} \mathrm{C}, 12 \mathrm{~s}$} & $259(\mathrm{~s} 1)$ & \multirow[t]{2}{*}[9,20]{} \\
\hline & & & & $286(\mathrm{~s} 2)$ & \\
\hline & Reverse & CTGCTTGAATGCGCCAAAC & & & \\
\hline \multirow[t]{2}{*}{ vacA s1a } & Forward & GTCAGCATCACACCGCAAC & \multirow[t]{2}{*}{$95^{\circ} \mathrm{C}, 10 \mathrm{~s} ; 56{ }^{\circ} \mathrm{C}, 5 \mathrm{~s} ; 72{ }^{\circ} \mathrm{C}, 8 \mathrm{~s}$} & \multirow[t]{2}{*}{190} & \multirow[t]{2}{*}[21]{} \\
\hline & Reverse & CTGCTTGAATGCGCCAAAC & & & \\
\hline \multirow[t]{2}{*}{$v a c A \mathrm{~s} 1 \mathrm{~b}$} & Forward & AGCGCCATACCGCAAGAG & \multirow[t]{2}{*}{$95^{\circ} \mathrm{C}, 10 \mathrm{~s} ; 56{ }^{\circ} \mathrm{C}, 5 \mathrm{~s} ; 72{ }^{\circ} \mathrm{C}, 8 \mathrm{~s}$} & \multirow[t]{2}{*}{187} & \multirow[t]{2}{*}[21]{} \\
\hline & Reverse & CTGCTTGAATGCGCCAAAC & & & \\
\hline \multirow[t]{2}{*}{$v a c A \mathrm{~s} 1 \mathrm{c}$} & Forward & TTAGTTTCTCTCGCTTTAGTRGGGYT & \multirow[t]{2}{*}{$95^{\circ} \mathrm{C}, 10 \mathrm{~s} ; 60{ }^{\circ} \mathrm{C}, 5 \mathrm{~s} ; 72{ }^{\circ} \mathrm{C}, 9 \mathrm{~s}$} & \multirow[t]{2}{*}{220} & \multirow[t]{2}{*}{ [19] } \\
\hline & Reverse & CTGCTTGAATGCGCCAAAC & & & \\
\hline \multirow[t]{2}{*}{ vacA $\mathrm{m} 1$} & Forward & GGTCAAAATGCGGTCATGG & \multirow[t]{2}{*}{$95^{\circ} \mathrm{C}, 10 \mathrm{~s} ; 56{ }^{\circ} \mathrm{C}, 5 \mathrm{~s} ; 72^{\circ} \mathrm{C}, 12 \mathrm{~s}$} & \multirow[t]{2}{*}{290} & \multirow[t]{2}{*}[9,22]{} \\
\hline & Reverse & CCATTGGTACCTGTAGAAAC & & & \\
\hline \multirow[t]{2}{*}{ vacA $\mathrm{m} 2$} & Forward & GGAGCCCCAGGAAACATTG & \multirow[t]{2}{*}{$95^{\circ} \mathrm{C}, 10 \mathrm{~s} ; 54{ }^{\circ} \mathrm{C}, 5 \mathrm{~s} ; 72^{\circ} \mathrm{C}, 15 \mathrm{~s}$} & \multirow[t]{2}{*}{352} & {$[9,22]$} \\
\hline & Reverse & CATAACTAGCGCCTTGCAC & & & \\
\hline iceAl & Forward & GTGTTTTTAACCAAAGTATC & $95^{\circ} \mathrm{C}, 10 \mathrm{~s} ; 51^{\circ} \mathrm{C}, 5 \mathrm{~s} ; 72^{\circ} \mathrm{C}, 10 \mathrm{~s}$ & 247 & {$[20,21]$} \\
\hline & Reverse & CTATAGCCASTYTCTTTGCA & & & \\
\hline iceA2 & Forward & GTTGGGTATATCACAATTTAT & $95^{\circ} \mathrm{C}, 10 \mathrm{~s} ; 51^{\circ} \mathrm{C}, 5 \mathrm{~s} ; 72^{\circ} \mathrm{C}, 14 \mathrm{~s}$ & 229 or 334 & {$[20,21]$} \\
\hline & Reverse & TTRCCCTATTTTCTAGTAGGT & & & \\
\hline$b a b A 2$ & Forward & AATCCAAAAAGGAGAAAAAGTATGAAA & $95^{\circ} \mathrm{C}, 10 \mathrm{~s} ; 60^{\circ} \mathrm{C}, 5 \mathrm{~s} ; 72^{\circ} \mathrm{C}, 34 \mathrm{~s}$ & 832 & {$[22]$} \\
\hline & Reverse & TGTTAGTGATTTCGGTGTAGGACA & & & \\
\hline
\end{tabular}

accordance with the Declaration of Helsinki, the International Conference on Harmonisation Good Clinical Practice Guidelines, and applicable local laws and regulations. Signed informed consent was obtained from each patient.

\section{Results}

Epidemiology and Histopathology

A total of 148 patients with infection by a single strain of $H$. pylori and complete histological evaluation were included. Their mean age was $43.5 \pm 13.4$ years (range 18-78) and 101 (68.2\%) had less than 50 years. Thirtyeight $(25.7 \%)$ were male, $84(56.8 \%)$ lived in a rural area, $33(22.3 \%)$ and $24(16.2 \%)$ had history of alcohol and tobacco consumption, respectively. These patients were referred for $H$. pylori eradication for one or more of the following reasons: non-ulcer dyspepsia$65.5 \%$; chronic therapy with proton pump inhibitors-
$24.3 \%$; iron-deficient anemia-20.3\%; first-degree relatives with gastric cancer-18.9\%; peptic ulcer-8.1\%. Gastritis classification according to updated Sydney system is presented in Table 2. The average chronic inflammation, neutrophil activity, glandular atrophy and intestinal metaplasia scores in the antrum were significantly higher than in the corpus. That did not happen with $H$. pylori density scores. We found no cases of epithelial dysplasia.

Older individuals ( $\geq 50$ years) presented higher degrees of neutrophil activity for body (OR 2.68; $95 \%$ CI 1.24-5.79) and antrum (OR 2.98; 95\%; CI 1.39-6.38), atrophy for antrum (OR 5.13; $95 \%$ CI 1.89-13.94) and OLGA stages (levels I-III: $\geq 50$ years-31.9\% versus $<50$ years-6.9\%; $p=0.001)$. Residence in urban areas was significantly associated with greater chronic inflammation levels in the antrum (OR 3.04; $95 \%$ CI 1.48-6.22). There was no correlation of histopathological findings with gender, history of former $H$. pylori eradication and alcohol/ tobacco consumption. 
Table 2 Classification of gastritis according to updated Sydney system

\begin{tabular}{|c|c|c|c|}
\hline Classification/grade & Antrum $(n)$ & Corpus $(n)$ & $p$ \\
\hline Atrophy & & & 0.008 \\
\hline 0 & $128(86.5 \%)$ & $144(97.2 \%)$ & \\
\hline 1 & $19(12.8 \%)$ & $2(1.4 \%)$ & \\
\hline 2 & $1(0.7 \%)$ & $1(0.7 \%)$ & \\
\hline 3 & $0(0 \%)$ & $1(0.7 \%)$ & \\
\hline Chronic inflammation & & & $<0.0001$ \\
\hline 0 & $0(0 \%)$ & $15(10.1 \%)$ & \\
\hline 1 & $101(68.2 \%)$ & $120(81.1 \%)$ & \\
\hline 2 & $47(31.8 \%)$ & $11(7.4 \%)$ & \\
\hline 3 & $0(0 \%)$ & $2(1.4 \%)$ & \\
\hline Neutrophil activity & & & $<0.0001$ \\
\hline 0 & $3(2.1 \%)$ & $28(18.9 \%)$ & \\
\hline 1 & $60(40.5 \%)$ & $83(56.1 \%)$ & \\
\hline 2 & $65(43.9 \%)$ & $31(20.9 \%)$ & \\
\hline 3 & $20(13.5 \%)$ & $6(4.1 \%)$ & \\
\hline Intestinal metaplasia & & & 0.005 \\
\hline 0 & $126(85.1 \%)$ & $141(95.2 \%)$ & \\
\hline 1 & $18(12.1 \%)$ & $5(3.4 \%)$ & \\
\hline 2 & $3(2.1 \%)$ & $1(0.7 \%)$ & \\
\hline 3 & $1(0.7 \%)$ & $1(0.7 \%)$ & \\
\hline $\begin{array}{l}\text { Density of } H . \text { pylori } \\
\text { colonization }\end{array}$ & & & 0.571 \\
\hline 0 & $2(1.4 \%)$ & $1(0.7 \%)$ & \\
\hline 1 & $106(71.6 \%)$ & $111(75 \%)$ & \\
\hline 2 & $30(20.3 \%)$ & $28(18.9 \%)$ & \\
\hline 3 & $10(6.7 \%)$ & $8(5.4 \%)$ & \\
\hline
\end{tabular}

Bold values are statistically significant

\section{Genotype Distribution}

Genotype distribution according with real-time PCR is presented in Table 3. Twenty-four of the 28 isolates $(85.7 \%)$ with genotype vacA $\mathrm{s} 1 \mathrm{~m} 1$ were $\operatorname{cag} A$ positive, and this relation was statistically significant (OR 25.30; $95 \%$ CI 7.99-80.07). An inverse relationship was found between cagA and vacA s2m2 (OR 0.06; $95 \%$ CI $0.02-0.15)$. Thirteen of the 18 strains (72.2\%) positive for babA2 also had $\operatorname{cagA}$ (OR 7.34; $95 \%$ CI 2.44-22.12).

Correlation of Genotype with Clinical Manifestations, Histopathology and Epidemiological Factors

Correlation between specific genotypes and clinical manifestations/indication for $H$. pylori eradication is presented in Table 4.

When we compared epidemiological characteristics with $H$. pylori genotypes, we found a significant association of male sex with vacA m1 (OR 3.23; $95 \%$ CI 1.39-7.14) and vacA s1m1 (OR 3.33; $95 \%$ CI 1.39-7.69).
Table 3 Genotype distribution for all $148 \mathrm{H}$. pylori isolates

\begin{tabular}{lc}
\hline Genotype & $n(\%)$ \\
\hline cagA positive & $47(31.8 \%)$ \\
cagE positive & $68(45.9 \%)$ \\
vacA s & \\
vacA s1 & $66(44.6 \%)$ \\
vacA s1a & $36(24.3 \%)$ \\
vacA s1b & $29(19.6 \%)$ \\
vacA s1c & $1(0.7 \%)$ \\
vacA $\mathrm{s} 2$ & $82(55.4 \%)$ \\
vacA $\mathrm{m}$ & $31(20.9 \%)$ \\
vacA $\mathrm{m} 1$ & $117(79.1 \%)$ \\
vacA $\mathrm{m} 2$ & \\
vacA $\mathrm{s}+\mathrm{m}$ & $28(18.9 \%)$ \\
vacA $\mathrm{s} 1 \mathrm{~m} 1$ & $38(25.7 \%)$ \\
vacA $\mathrm{s} 1 \mathrm{~m} 2$ & $3(2 \%)$ \\
vacA s2m1 & $79(53.4 \%)$ \\
vacA $\mathrm{s} 2 \mathrm{~m} 2$ & \\
iceA & $50(33.8 \%)$ \\
iceA1 & $98(66.2 \%)$ \\
iceA2 & $18(12.2 \%)$ \\
babA2 &
\end{tabular}

An overview of genotype distribution and its relationship with histopathological characteristics is presented in Tables 5 and 6. Distribution according to OLGA and OLGIM staging systems is presented in Table 7. For OLGA, there were no cases of patients in stages IV and the same happened for OLGIM in stage III so we suppressed such categories from the tables. Values for vacA $\mathrm{m} 2$ and iceA2 are the opposite ones from vacA $\mathrm{m} 1$ and iceAl, and we also removed it from the tables. The same happened with vacA s1c since we had only one positive isolate with this $\mathrm{s} 1$ subtype.

Combined genotype cagA positive $+v a c A$ s $1 \mathrm{~m} 1$ was more common in patients with peptic ulcer (OR 6.56; $95 \%$ CI 1.91-22.55), higher degrees of neutrophil activity in the body (OR 3.96; $95 \%$ CI 1.59-9.86) and antrum (OR 4.54; $95 \%$ CI 1.47-14.05).

Genotype $\operatorname{cag} A$ positive $+v a c A \operatorname{sim} 1+b a b A 2$ positive occurred in 7 cases (4.7\%). It was significantly related with higher degrees of $H$. pylori colonization in the body (OR 22.20; $95 \%$ CI 2.57-191.55) and antrum (OR 7.57; $95 \%$ CI 1.41-40.78) and was more frequent in patients with peptic ulcer (OR 11.00; $95 \%$ CI 2.13-56.83).

In a logistic regression analysis including epidemiological factors as potential confounders, we recognized the subsequent significant associations: presence of intestinal metaplasia in the antrum with cagA (OR 3.76; $95 \% \mathrm{CI}$ 1.26-11.24); higher levels of neutrophil activity in the antrum with cagA (OR 2.58; $95 \%$ CI 1.12-5.95); 


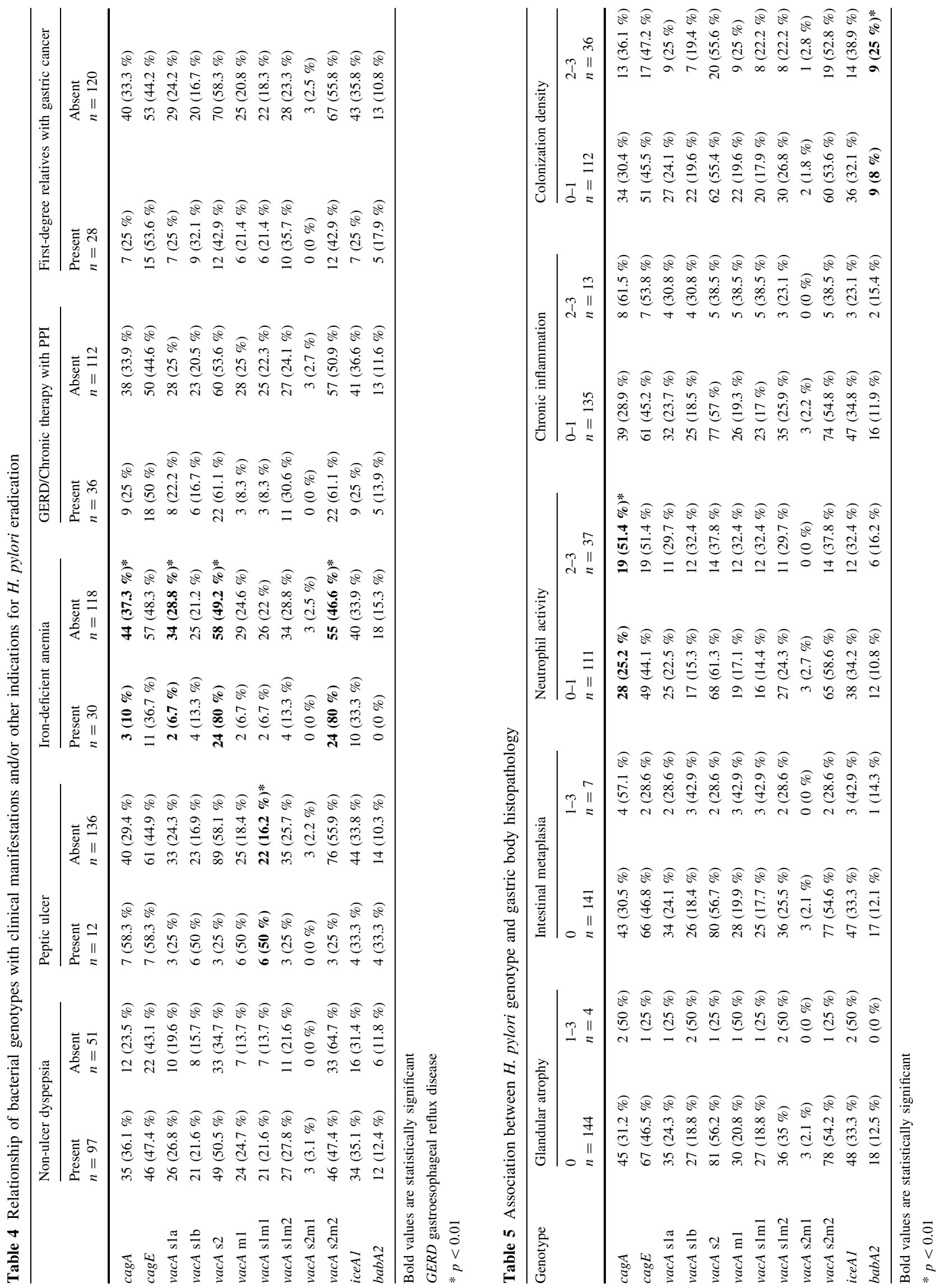




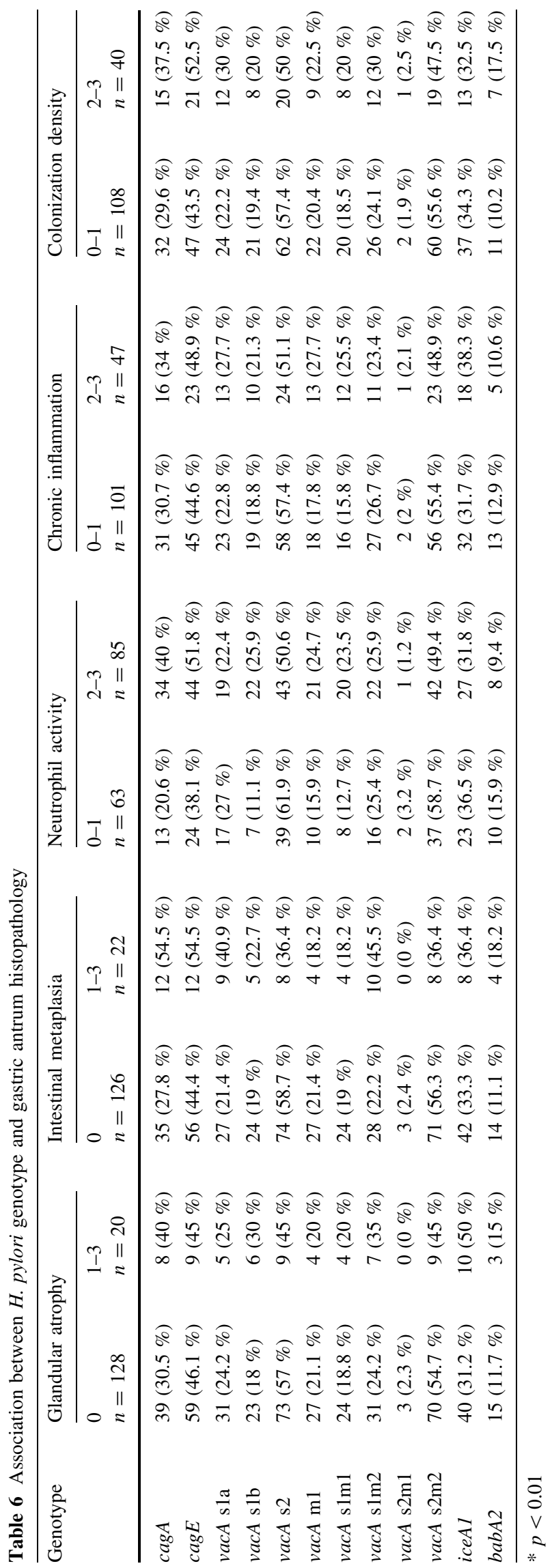

advanced levels of chronic inflammation in the body with cagA (OR 4.61; $95 \%$ CI 1.37-15.63); higher H. pylori density scores in the body with babA2 (OR 7.46; $95 \% \mathrm{CI}$ 2.15-26.32).

\section{Discussion}

Although $H$ pylori affects approximately $50 \%$ of all humans only a minority develop manifestations associated with this infection. H pylori exceptional genetic variability and intraspecies diversity contributes to this discrepancy [23]. There is a geographic variability of $H$. pylori genotypes [20,24]. Patients infected with more virulent strains have higher probabilities of developing complications [5]. Conclusions about the relation between $H$. pylori genotypes and different clinical outcomes, if derived from a single geographic region, may not be true for other geographic locations [19]. It is important to determine the most prevalent genotypes in a specific region and to confirm whether there is a correlation between putative virulence genes and histological markers of severity. In areas of high $H$. pylori infection prevalence, this information may potentially help us to predict whether there is an increased risk of gastric adenocarcinoma.

To our knowledge, this paper presents the largest characterization to date of $H$. pylori isolates and associated histopathological modifications collected from persons living in the central region of Portugal. Our study population is rather young but, even so, we demonstrated that glandular atrophy, neutrophil activity, and OLGA stages were significantly higher in older patients. Infection generally occurs during childhood and development of more severe histopathological manifestations, such as intestinal metaplasia and glandular atrophy, are linked to prolonged infection and consequently to patients' age $[25,26]$. A study performed in the northern part of the country also revealed that patients with atrophic gastritis were significantly older than the ones with no atrophy [5].

A remarkable result was the higher degrees of intestinal metaplasia, glandular atrophy, neutrophil activity and chronic inflammation in the antrum comparatively to the body confirming that $H$. pylori infection in our patients induces more histological changes in the antrum. According to the classification of chronic gastritis, antral predominant non-atrophic gastritis was the dominant pattern in our cohort [17]. Most patients affected by this condition have only a minimally increased risk of adenocarcinoma of the distal stomach when compared with uninfected individuals $[17,27]$.

One of the most important virulence factors of $H$. pylori is cagA that is present in about $60-70 \%$ of the Western strains and in more than $90 \%$ of the East Asian ones [7, 
Table 7 Relationship between H. pylori genotype and OLGA/ OLGIM staging systems

\begin{tabular}{|c|c|c|c|c|c|c|c|c|c|c|c|c|}
\hline \multirow[t]{2}{*}{ Genotype (\%) } & & \multirow[t]{2}{*}{$n$} & \multicolumn{4}{|c|}{ OLGA } & \multirow[t]{2}{*}{$p$} & \multicolumn{4}{|c|}{ OLGIM } & \multirow[t]{2}{*}{$p$} \\
\hline & & & 0 & I & II & III & & 0 & I & II & IV & \\
\hline \multirow[t]{2}{*}{$\operatorname{cag} A$} & + & 47 & 83 & 10.6 & 4.3 & 2.1 & NS & 68.1 & 21.3 & 8.5 & 2.1 & 0.001 \\
\hline & - & 101 & 86.1 & 13.9 & 0 & 0 & & 88.1 & 11.9 & 0 & 0 & \\
\hline \multirow[t]{2}{*}{$\operatorname{cag} E$} & + & 68 & 85.3 & 14.7 & 0 & 0 & NS & 83.8 & 12.5 & 2.5 & 1.2 & NS \\
\hline & - & 80 & 85.1 & 11.2 & 2.5 & 1.2 & & 79.4 & 17.6 & 3 & 0 & \\
\hline \multirow[t]{2}{*}{ vacA s1a } & + & 36 & 86.1 & 11.1 & 2.8 & 0 & NS & 72.3 & 19.4 & 8.3 & 0 & NS \\
\hline & - & 112 & 84.8 & 13.4 & 0.9 & 0.9 & & 84.8 & 13.4 & 0.9 & 0.9 & \\
\hline \multirow[t]{2}{*}{$v a c A \mathrm{~s} 1 \mathrm{~b}$} & + & 29 & 75.9 & 17.3 & 3.4 & 3.4 & NS & 75.9 & 17.3 & 3.4 & 3.4 & NS \\
\hline & - & 119 & 87.4 & 11.8 & 0.8 & 0 & & 83.2 & 14.3 & 2.5 & 0 & \\
\hline \multirow[t]{2}{*}{$v a c A$ s2 } & + & 82 & 87.8 & 12.2 & 0 & 0 & NS & 87.8 & 12.2 & 0 & 0 & NS \\
\hline & - & 66 & 81.8 & 13.6 & 3.1 & 1.5 & & 74.2 & 18.2 & 6.1 & 1.5 & \\
\hline \multirow[t]{2}{*}{ vacA $\mathrm{m} 1$} & + & 31 & 87.1 & 9.7 & 3.2 & 0 & NS & 77.4 & 19.4 & 3.2 & 0 & NS \\
\hline & - & 115 & 84.6 & 13.6 & 0.9 & 0.9 & & 82.8 & 13.7 & 2.6 & 0.9 & \\
\hline \multirow[t]{2}{*}{$v a c A \mathrm{~s} 1 \mathrm{~m} 1$} & + & 28 & 85.7 & 10.7 & 3.6 & 0 & NS & 75 & 21.4 & 3.6 & 0 & NS \\
\hline & - & 120 & 85.1 & 13.3 & 0.8 & 0.8 & & 83.3 & 13.4 & 2.5 & 0.8 & \\
\hline \multirow[t]{2}{*}{$v a c A \mathrm{~s} 1 \mathrm{~m} 2$} & + & 38 & 79 & 15.8 & 2.6 & 2.6 & NS & 73.7 & 15.8 & 7.9 & 2.6 & NS \\
\hline & - & 110 & 87.3 & 11.8 & 0.9 & 0 & & 84.5 & 14.5 & 1 & 0 & \\
\hline \multirow[t]{2}{*}{$v a c A \mathrm{~s} 2 \mathrm{~m} 1$} & + & 3 & 100 & 0 & 0 & 0 & NS & 100 & 0 & 0 & 0 & NS \\
\hline & - & 145 & 84.8 & 13.1 & 1.4 & 0.7 & & 81.4 & 15.2 & 2.8 & 0.7 & \\
\hline \multirow[t]{2}{*}{$v a c A \mathrm{~s} 2 \mathrm{~m} 2$} & + & 79 & 87.3 & 12.7 & 0 & 0 & NS & 87.3 & 12.7 & 0 & 0 & NS \\
\hline & - & 69 & 82.6 & 13 & 2.9 & 1.4 & & 75.4 & 17.4 & 5.8 & 1.4 & \\
\hline \multirow[t]{2}{*}{ iceAl } & + & 50 & 80 & 14 & 4 & 2 & NS & 82 & 12 & 4 & 2 & NS \\
\hline & - & 98 & 87.8 & 12.2 & 0 & 0 & & 81.6 & 16.3 & 2 & 0 & \\
\hline \multirow[t]{2}{*}{$b a b A 2$} & + & 18 & 83.3 & 11.1 & 5.6 & 0 & NS & 72.2 & 16.7 & 11.1 & 0 & NS \\
\hline & - & 130 & 85.4 & 13.1 & 0.8 & 0.8 & & 83.1 & 14.6 & 1.5 & 0.8 & \\
\hline
\end{tabular}

28, 29]. In our study cagA genotype, albeit determined by real-time PCR using two different sets of primers, was identified in only $31.8 \%$ of isolates. This is considerably less than it was previously published for our country [5, 30]. There are different possible explanations for this finding. First, cagA is more common in $H$. pylori infection associated with peptic ulcer or gastric carcinoma. In our study, $65.5 \%$ of patients had non-ulcer dyspepsia and only $8.1 \%$ had peptic ulcer. There were no cases of gastric carcinoma. Van Doorn et al. [24] also presented a prevalence of cagA-positive strains of only $35.7 \%$ in Egypt, where most of the isolates were from non-ulcer patients. Another possible explanation is that there is a national and regional heterogeneity in distribution of $\mathrm{H}$. pylori genotypes and in the Central region of Portugal cagA negative strains might be more common. Some authors already stated that there are regional bacterial populations with particular attributes making it difficult to establish universal virulence markers [31]. A recent study performed in a region with one of the highest incidence and mortality from gastric carcinoma in Spain and Western Europe revealed a low prevalence of $c a g A$-positive strains (47.7\% of infected patients) [32]. Another recent study, from a different Mediterranean country, also revealed a low prevalence of cagA-positive strains $(42.3 \%)$ [33]. In a Jordanian study, only $26.9 \%$ of $H$. pylori isolates were cagA positive [34]. However, albeit relatively rare in our study population, $\operatorname{cag} A$ maintained a significant relation with vacA $\mathrm{s} 1 \mathrm{~m} 1$, as already stated by multiple articles $[10$, $32,33,35]$. Although $\operatorname{cag} A$ was found in only $31.8 \%$ of isolates, $c a g$ PAI was more frequent since $c a g E$ was present in $45.9 \%$. A recent study, from Brazil, also reported higher prevalence of $c a g E$ comparatively to $c a g A$ [31]. H. pylori microevolution can determine loss of all or part of the cagPAI [23]. In Japanese and French studies, $c a g E$ was found to be a better marker for the presence of $c a g$ PAI than cagA [36, 37]. We did not perform detection of cagPAI empty site, and this is a limitation of our work. It is interesting to notice that a recent study, in Portuguese children, demonstrated a low prevalence $(16.7 \%)$ of cagPAI in patients with non-ulcer dyspepsia comparatively to patients with peptic ulcer disease (75.4\%) [38].

In European and North American populations, $\operatorname{cagA}$ has been associated with more severe disease such as gastric mucosal atrophy, intestinal metaplasia and gastric cancer $[6,10,39,40]$. We think the same is valid for the central 
region of Portugal since $\operatorname{cag} A$-positive status was independently associated with presence of intestinal metaplasia in the antrum, higher degrees of neutrophil activity in the antrum and chronic inflammation in the body as well as higher OLGIM stages. So, this genotype, although rare in our population, was the most frequently related with worrisome histopathological features.

Gene $\operatorname{cag} E$ is also within the cag PAI and has been associated with a more severe clinical outcome [7]. In the central region of Portugal, cagE is more prevalent than $\operatorname{cag} A$ and has no relation with clinical presentation or gastric histopathology. In our population, this marker of cagPAI, although more frequent, is clearly less pathogenic than the cagA. Proença Modena et al. [31] also found no correlation of $c a g E$ with disease outcomes.

There are clear geographic differences in the distribution of both vacA s and $\mathrm{m}$ subtypes [24, 33]. The $H$. pylori vacA s1m1 genotype is the most common in American, European and East Asian countries [24, 29, 41-43]. The vacA $\mathrm{s} 2 \mathrm{~m} 2$ genotype is apparently less common and another study in Portugal, performed in patients submitted to a screening program, revealed a prevalence of $29.7 \%$ for such allele combination $(42.9 \%$ if multiple vacA genotypes were excluded). The $v a c A \mathrm{~s} 2 \mathrm{~m} 2$ prevalence found in our study is among the highest reported [24]. This was expected given the high prevalence of $\operatorname{cagA}$ negative strains and the association of such genetic profile with vacA $\mathrm{s} 2$ and vacA $\mathrm{m} 2$ [24]. This reflects the presence of less virulent strains in the central region of Portugal. However, we cannot forget that we have few cases with peptic ulcer disease and none with gastric cancer. A selection bias cannot be completely excluded, and this is a limitation of our work. Even so, it is interesting to notice that Boukhris et al. [33] identified a higher prevalence (59.2\%) of vacA $\mathrm{s} 2 \mathrm{~m} 2$ genotype in 145 Moroccan isolates with a single association of vacA $\mathrm{s}$ and $\mathrm{m}$ alleles. The same happened in another study in our neighbour, Spain, also with $v a c A \mathrm{~s} 2 \mathrm{~m} 2$ being the dominant genotype [32].

Mosaicism vacA s2m1 was detected in only 3 patients, confirming that this genotype is very rare $[9,10,24]$. Van Doorn et al. established that in the Iberian Peninsula subtype $\mathrm{s} 1 \mathrm{~b}$ was the dominant one $[24,44,45]$. By the contrary, our study demonstrates that in the central region s2 is the more common allele followed by s1a. It is known that $v a c A \mathrm{~s} 1 \mathrm{~m} 1$ strains determine higher levels of inflammation in the gastric mucosa and both $v a c A \mathrm{~s} 1 \mathrm{~m} 1$ and $\mathrm{s} 1 \mathrm{~m} 2$ strains may be disease-associated but patients with gastric cancer usually have the s1m1 type $[5,10,28,39,44,46]$. In our population, we found no correlations of vacA genotypes with gastric histopathological modifications. The last published data about gastric carcinoma epidemiology in Portugal revealed a low incidence rate in the central region comparatively to the south and north [47]. Predominance of less virulent strains in this part of the country could partially explain such differences. However, the relatively small number of isolates with $\mathrm{s} 1 \mathrm{~m} 1$ and $\mathrm{s} 1 \mathrm{~m} 2$ and the absence of patients with gastric carcinoma cannot allow us to confirm or deny this association. A larger, epidemiological population-based study would be necessary to clarify these doubts.

We identified an isolate with subtype s1c. This allelic variant is essentially detected in East Asian patients but some cases were already described in Westerners [7, 40, 41, 48].

The $\mathrm{m} 1$ allele is relatively rare compared with $\mathrm{m} 2$. This is also the opposite of what was previously established for the Iberian Peninsula but similar to the results presented more recently by González et al. for a specific Spanish region $[24,32]$.

The iceAl allelic variant of iceA may be linked with the development of peptic ulcers since iceAl positive strains produce more proinflammatory factor IL-8 [7, 49]. In our study, population iceA2 subtype was the dominant one, as previously stated for Western patients $[7,11,20,22]$. The relationship of iceA with gastric histopathology and clinical presentation is also very different from study to study [13, 20, 45]. In our work, we did not find any specific association of iceA allelic variants with pathological or clinical phenotype. Another study, involving patients from the northern region of the country, also failed to found a relation between the iceA allelic variants and clinical outcome of $H$. pylori infection [45].

The $b a b A 2$ gene has been strongly associated with $\operatorname{cag} A$ and $v a c A$ s1 in some populations [12]. Prevalence of $b a b A 2$ positive strains is very heterogeneous and can be as high as $92.3 \%[7,13,22]$. This genotype can determine a higher risk of ulcer and gastric adenocarcinoma but this is controversial [7]. In our study, $b a b A 2$ was very rare and only associated with higher $H$. pylori density scores in the gastric body. To confirm the real prevalence of $b a b A$, some authors recommend immunoblot as well as the use of several primer pairs by PCR because of possible sequence variations $[50,51]$.

Strains with vacA $\mathrm{s} 1 \mathrm{~m} 1$ as well as genotype combinations cagA positive $+v a c A$ s $1 \mathrm{~m} 1$ and $\operatorname{cag} A$ positive + $v a c A \operatorname{sim} 1+b a b A 2$ were associated with peptic ulcer. The correlation of such clinical manifestation with these genotypes is consistent with earlier studies [35, 41, 52]. This is explained by the higher virulence and mucosal injury determined by such strains. On the contrary, the less virulent $H$. pylori genotype vacA $\mathrm{s} 2 \mathrm{~m} 2$ was more common in asymptomatic patients, with iron-deficient anemia.

Traditionally, less aggressive vacA $\mathrm{s} 2 \mathrm{~m} 2$ strains are more common in patients with functional dyspepsia although some studies reported the opposite correlation 
$[53,54]$. In our study, no significant association with this clinical manifestation was detected.

A major limitation of our work is that we studied only a few genes and, as we know, the average size of an $\mathrm{H}$. pylori genome is estimated at $1.62 \mathrm{Mb}$ consisting of 1,590 openreading frames encoding 1,532 proteins [55]. Probably, in a near future, with increased availability of next-generation sequencing, multiple $H$. pylori complete genomes will be studied and we will discover and/or relate other genes and respective proteins as major factors for specific clinical manifestations of $H$. pylori infection as well as histological parameters of $H$. pylori related gastritis.

Another limitation was the relatively low number of patients with specific histopathological modifications (e.g., corpus glandular atrophy) and clinical manifestations. We had only 12 patients with peptic ulcer and none with gastric cancer. We even had a large number of patients referred for H. pylori eradication only because they had first-degree relatives with gastric cancer. Our hospital is a tertiaryreferral center, and we included only patients from ambulatory clinical practice. Obviously, the ones with complicated peptic ulcers or gastric cancers are referred for admission and specific treatment. A population-based study could, eventually, overcome this problem.

Genetic factors for infected host can be a very important determinant of infection result. Not including this variable in our work is a major restraint.

H. pylori induces chronic gastritis in virtually all infected patients [26, 32]. However, gastritis and preneoplastic lesions such as glandular atrophy and intestinal metaplasia also occur in uninfected patients. Our work did not involve $H$. pylori negative controls and so we do not know the real correlation of gastric histopathological modifications with $H$. pylori infection.

Finally, most authors that study this problem consider all patients, including the ones with multiple $H$. pylori genotypes. Previous studies in Portugal revealed a high prevalence of patients harboring multiple $H$. pylori strains [5, 21, 45]. However, for correlation of $H$. pylori genotypes with gastric histopathology, most authors exclude patients with multiple isolates. In our opinion, this strategy can be somehow confuse and difficult to interpret so we decided to consider only patients with single $H$. pylori genotypes.

\section{Conclusions}

Higher scores of intestinal metaplasia and gastric mucosa inflammation are detected in patients infected by $\operatorname{cagA}$ positive $H$. pylori isolates confirming the increased virulence of such strains and the potentially worst outcomes in these cases. IceA2 allelic variant is the predominant one and has no correlation with disease phenotype. Gene babA2 is rare and associated with higher $H$. pylori colonization density in the corpus.

Patients with peptic ulcer are frequently infected by $H$. pylori with the vacA $\mathrm{s} 1 \mathrm{~m} 1$ allelic variant or the combination $\operatorname{cag} A+v a c A \quad \mathrm{~s} 1 \mathrm{~m} 1$ and $\operatorname{cag} A$ positive $+v a c A$ $\mathrm{s} 1 \mathrm{~m} 1+b a b A 2$.

In the central region of Portugal, there is a predominance of less virulent strains while maintaining the usual correlation with gastric histopathology. This implies low prevalence of gastric atrophy and/or intestinal metaplasia and hypothetically, of gastric adenocarcinoma. Our results, compared with earlier published ones, from other regions, demonstrate that, in the same country, H. pylori genotype may have a marked regional variability.

Acknowledgments We are deeply indebted to Professor Javier Gisbert for all comments and suggestions about this manuscript. We also want to thank Dr João Casalta for all support provided in statistical analysis. This work was part of a project designed to study primary and secondary resistance of Helicobacter pylori to antimicrobial agents, supported by the Portuguese Institute Fundação para a Ciência e a Tecnologia (PIC/IC/83122/2007).

Conflict of interest There are no conflicts of interest to disclose.

\section{References}

1. Malfertheiner P, Megraud F, O'Morain CA, et al. Management of Helicobacter pylori infection-the Maastricht IV/Florence consensus report. Gut. 2012;61:646-664.

2. Chuah SK, Tsay FW, Hsu PI, Wu DC. A new look at anti-Helicobacter pylori therapy. World J Gastroenterol. 2011;17:3971-3975.

3. Bastos J, Peleteiro B, Barros R, et al. Sociodemographic determinants of prevalence and incidence of Helicobacter pylori infection in Portuguese adults. Helicobacter. 2013;18:413-422.

4. Robinson K, Argent RH, Atherton JC. The inflammatory and immune response to Helicobacter pylori infection. Best Pract Res Clin Gastroenterol. 2007;21:237-259.

5. Nogueira C, Figueiredo C, Carneiro F, et al. Helicobacter pylori genotypes may determine gastric histopathology. Am J Pathol. 2001;158:647-654.

6. Blaser MJ, Perez-Perez GI, Kleanthous H, et al. Infection with Helicobacter pylori strains possessing cagA is associated with an increased risk of developing adenocarcinoma of the stomach. Cancer Res. 1995;55:2111-2115.

7. Chomvarin C, Namwat W, Chaicumpar K, et al. Prevalence of Helicobacter pylori vacA, cagA, cagE, iceA and babA2 genotypes in Thai dyspeptic patients. Int J Infect Dis. 2008;12: 30-36.

8. Sugimoto M, Yamaoka Y. Virulence factor genotypes of Helicobacter pylori affect cure rates of eradication therapy. Arch Immunol Ther Exp. 2009;57:45-56.

9. Atherton JC, Cao P, Peek RM Jr, Tummuru MK, Blaser MJ, Cover TL. Mosaicism in vacuolating cytotoxin alleles of Helicobacter pylori. Association of specific vacA types with cytotoxin production and peptic ulceration. J Biol Chem. 1995;270: 17771-17777.

10. Basso D, Zambon CF, Letley DP, et al. Clinical relevance of Helicobacter pylori cagA and vacA gene polymorphisms. Gastroenterology. 2008;135:91-99. 
11. Shiota S, Watada M, Matsunari O, Iwatani S, Suzuki R, Yamaoka Y. Helicobacter pylori iceA, clinical outcomes, and correlation with cagA: a meta-analysis. PloS One. 2012;7:e30354.

12. Gerhard M, Lehn N, Neumayer N, et al. Clinical relevance of the Helicobacter pylori gene for blood-group antigen-binding adhesin. Proc Natl Acad Sci USA. 1999;96:12778-12783.

13. Chiurillo MA, Moran Y, Canas M, et al. Genotyping of Helicobacter pylori virulence-associated genes shows high diversity of strains infecting patients in western Venezuela. Int $J$ Infect Dis. 2013;17:e750-e756.

14. Dixon MF, Genta RM, Yardley JH, Correa P. Classification and grading of gastritis. The updated Sydney system. International workshop on the histopathology of gastritis, Houston 1994. Am J Surg Pathol. 1996;20:1161-1181.

15. Capelle LG, de Vries AC, Haringsma J, et al. The staging of gastritis with the OLGA system by using intestinal metaplasia as an accurate alternative for atrophic gastritis. Gastrointest Endosc. 2010;71:1150-1158.

16. Rugge M, Correa P, Di Mario F, et al. OLGA staging for gastritis: a tutorial. Dig Liver Dis. 2008;40:650-658.

17. Rugge M, Genta RM. Staging and grading of chronic gastritis. Hum Pathol. 2005;36:228-233.

18. Santos A, Queiroz DM, Menard A, et al. New pathogenicity marker found in the plasticity region of the Helicobacter pylori genome. J Clin Microbiol. 2003;41:1651-1655.

19. Erzin Y, Koksal V, Altun S, et al. Prevalence of Helicobacter pylori vacA, cagA, cagE, iceA, babA2 genotypes and correlation with clinical outcome in Turkish patients with dyspepsia. Helicobacter. 2006;11:574-580.

20. Yamaoka Y, Kodama T, Gutierrez O, Kim JG, Kashima K, Graham DY. Relationship between Helicobacter pylori iceA, cagA, and vacA status and clinical outcome: studies in four different countries. J Clin Microbiol. 1999;37:2274-2279.

21. van Doorn LJ, Figueiredo C, Rossau R, et al. Typing of Helicobacter pylori vacA gene and detection of cagA gene by PCR and reverse hybridization. J Clin Microbiol. 1998;36:1271-1276.

22. Podzorski RP, Podzorski DS, Wuerth A, Tolia V. Analysis of the vacA, cagA, cagE, iceA, and babA2 genes in Helicobacter pylori from sixty-one pediatric patients from the Midwestern United States. Diagn Microbiol Infect Dis. 2003;46:83-88.

23. Armitano RI, Matteo MJ, Goldman C, et al. Helicobacter pylori heterogeneity in patients with gastritis and peptic ulcer disease. Infect Genet Evol. 2013;16:377-385.

24. Van Doorn LJ, Figueiredo C, Megraud F, et al. Geographic distribution of vacA allelic types of Helicobacter pylori. Gastroenterology. 1999;116:823-830.

25. Warburton VJ, Everett S, Mapstone NP, Axon AT, Hawkey P, Dixon MF. Clinical and histological associations of cagA and vacA genotypes in Helicobacter pylori gastritis. J Clin Pathol. 1998;51:55-61.

26. Alaoui Boukhris S, Amarti A, El Rhazi K, et al. Helicobacter pylori genotypes associated with gastric histo-pathological damages in a moroccan population. PloS One. 2013;8(12):e82646.

27. Graham DY. Helicobacter pylori infection in the pathogenesis of duodenal ulcer and gastric cancer: a model. Gastroenterology. 1997;113:1983-1991.

28. Ferreira RM, Machado JC, Letley D, et al. A novel method for genotyping the Helicobacter pylori vacA intermediate region directly in gastric biopsy specimens. J Clin Microbiol. 2012;50: 3983-3989.

29. Kim SY, Woo CW, Lee YM, et al. Genotyping CagA, VacA subtype, IceA1, and BabA of Helicobacter pylori isolates from Korean patients, and their association with gastroduodenal diseases. J Korean Med Sci. 2001;16:579-584.

30. Marcos-Pinto R, Dinis-Ribeiro M, Carneiro F, et al. First-degree relatives of early-onset gastric cancer patients show a high risk for gastric cancer: phenotype and genotype profile. Virchows Archiv. 2013;463:391-399.

31. Proenca Modena JL, Lopes Sales AI, Olszanski Acrani G, et al. Association between Helicobacter pylori genotypes and gastric disorders in relation to the cag pathogenicity island. Diagn Microbiol Infect Dis. 2007;59:7-16.

32. Gonzalez CA, Figueiredo C, Lic CB, et al. Helicobacter pylori cag A and vacA genotypes as predictors of progression of gastric preneoplastic lesions: a long-term follow-up in a high-risk area in Spain. Am J Gastroenterol. 2011;106:867-874.

33. Alaoui Boukhris S, Benajah DA, El Rhazi K, et al. Prevalence and distribution of Helicobacter pylori cagA and vacA genotypes in the Moroccan population with gastric disease. Eur J Clin Microbiol Infect Dis. 2012;31:1775-1781.

34. Nimri LF, Matalka I, Bani Hani K, Ibrahim M. Helicobacter pylori genotypes identified in gastric biopsy specimens from Jordanian patients. BMC Gastroenterol. 2006;6:27.

35. van Doorn LJ, Schneeberger PM, Nouhan N, Plaisier AP, Quint WG, de Boer WA. Importance of Helicobacter pylori cagA and vacA status for the efficacy of antibiotic treatment. Gut. 2000;46: 321-326.

36. Audibert C, Burucoa C, Janvier B, Fauchere JL. implication of the structure of the Helicobacter pylori cag pathogenicity island in induction of interleukin-8 secretion. Infect Immun. 2001;69: $1625-1629$.

37. Ikenoue T, Maeda S, Ogura K, et al. Determination of Helicobacter pylori virulence by simple gene analysis of the cag pathogenicity island. Clin Diagn Lab Immunol. 2001;8:181-186.

38. Oleastro M, Santos A, Cordeiro R, Nunes B, Megraud F, Menard A. Clinical relevance and diversity of two homologous genes encoding glycosyltransferases in Helicobacter pylori. J Clin Microbiol. 2010;48:2885-2891.

39. Figueiredo C, Machado JC, Pharoah P, et al. Helicobacter pylori and interleukin 1 genotyping: an opportunity to identify high-risk individuals for gastric carcinoma. J Natl Cancer Inst. 2002;94: 1680-1687.

40. Soltermann A, Koetzer S, Eigenmann F, Komminoth P. Correlation of Helicobacter pylori virulence genotypes vacA and cagA with histological parameters of gastritis and patient's age. Mod Pathol. 2007;20:878-883.

41. Miernyk K, Morris J, Bruden D, et al. Characterization of Helicobacter pylori cagA and vacA genotypes among Alaskans and their correlation with clinical disease. J Clin Microbiol. 2011;49: 3114-3121.

42. van Doorn LJ, Figueiredo C, Sanna R, et al. Clinical relevance of the cagA, vacA, and iceA status of Helicobacter pylori. Gastroenterology. 1998;115:58-66.

43. Ashour AA, Magalhaes PP, Mendes EN, et al. Distribution of vacA genotypes in Helicobacter pylori strains isolated from Brazilian adult patients with gastritis, duodenal ulcer or gastric carcinoma. FEMS Immunol Med Microbiol. 2002;33:173-178.

44. Yamaoka Y, Kato M, Asaka M. Geographic differences in gastric cancer incidence can be explained by differences between Helicobacter pylori strains. Intern Med. 2008;47:1077-1083.

45. Figueiredo C, Van Doorn LJ, Nogueira C, et al. Helicobacter pylori genotypes are associated with clinical outcome in Portuguese patients and show a high prevalence of infections with multiple strains. Scand J Gastroenterol. 2001;36:128-135.

46. Miehlke S, Kirsch C, Agha-Amiri K, et al. The Helicobacter pylori vacA $\mathrm{s} 1, \mathrm{~m} 1$ genotype and cagA is associated with gastric carcinoma in Germany. Int J Cancer J. 2000;87:322-327.

47. Norte RORd. Registo Oncológico Nacional. Pontes JM, editor2007 2007. $142 \mathrm{p}$.

48. van Doorn LJ, Figueiredo C, Sanna R, et al. Expanding allelic diversity of Helicobacter pylori vacA. J Clin Microbiol. 1998;36: 2597-2603. 
49. Xu Q, Blaser MJ. Promoters of the CATG-specific methyltransferase gene hpyIM differ between iceA1 and iceA2 Helicobacter pylori strains. J Bacteriol. 2001;183:3875-3884.

50. Boyanova L, Yordanov D, Gergova G, Markovska R, Mitov I. Association of iceA and babA genotypes in Helicobacter pylori strains with patient and strain characteristics. Antonie van Leeuwenhoek. 2010;98:343-350.

51. Yamaoka Y. Roles of Helicobacter pylori BabA in gastroduodenal pathogenesis. World J Gastroenterol. 2008;14:4265-4272.

52. Olfat FO, Zheng Q, Oleastro M, et al. Correlation of the Helicobacter pylori adherence factor BabA with duodenal ulcer disease in four European countries. FEMS Immunol Med Microbiol. 2005;44:151-156.
53. Rudi J, Rudy A, Maiwald M, Kuck D, Sieg A, Stremmel W. Direct determination of Helicobacter pylori vacA genotypes and cagA gene in gastric biopsies and relationship to gastrointestinal diseases. Am J Gastroenterol. 1999;94:1525-1531.

54. Arevalo-Galvis A, Trespalacios-Rangell AA, Otero W, MercadoReyes MM, Poutou-Pinales RA. Prevalence of cagA, vacA, babA2 and iceA genes in $H$. pylori strains isolated from Colombian patients with functional dyspepsia. Pol Soc Microbiol. 2012;61:33-40.

55. Ahmed N, Loke MF, Kumar N, Vadivelu J. Helicobacter pylori in 2013: multiplying genomes, emerging insights. Helicobacter. 2013;18:1-4. 